\title{
Does legal system matter for directed technical change? Evidence from the auto industry
}

\section{Per G. Fredriksson \& Alexandre Sauquet}

To cite this article: Per G. Fredriksson \& Alexandre Sauquet (2016): Does legal system matter for directed technical change? Evidence from the auto industry, Applied Economics Letters, DOI: 10.1080/13504851.2016.1254334

To link to this article: http://dx.doi.org/10.1080/13504851.2016.1254334

曲 Published online: 07 Nov 2016.

Submit your article to this journal 준

Џ Article views: 17

Q View related articles ¿

View Crossmark data $₫$ 


\title{
Does legal system matter for directed technical change? Evidence from the auto industry
}

\author{
Per G. Fredriksson ${ }^{\mathrm{a}}$ and Alexandre Sauquet ${ }^{\mathrm{b}}$ \\ aDepartment of Economics, University of Louisville, Louisville, KY, USA; 'NRA, UMR 1135 LAMETA, Montpellier, France
}

ABSTRACT

Does the effect of fuel taxes on clean innovations (e.g. hybrid technology) depend on the legal system's rigidity? Using 1986-2005 data from more than 1900 firms, evidence suggests that autoindustry firms located in civil law (with more rigid laws) countries increase clean technology patenting more than common law (with more flexible laws) firms when the tax-inclusive fuel price rises. A rigid legal system appears to raise clean technology innovation.
KEYWORDS

Innovation; clean technology; directed technical change; legal origin; energy policy

JEL CLASSIFICATION O31; K49; Q58; Q48

\section{Introduction}

Climate change is a major public policy issue. Technological innovation encouraged by government tax policy (directed technical change) is a possible response (Acemoglu et al., 2012). Aghion et al. (2016) (hereafter, ADHMV) show that auto firms patent more clean technologies when the encounter higher tax-inclusive fuel prices. They also document path-dependence in innovation due to other firms' and own prior innovation history. Anderlini et al. (2013) argue that legal institutions influence the speed of technical change due to different levels of flexibility.

We study how the legal regime influences innovation, in particular auto firms' clean technology innovationresponses to tax-inclusive fuel price movements, a topic largely ignored by the empirical literature. Our analysis should help predict the impact of directed technical change in countries with different legal systems. Beck, Demirgüç-Kunt, and Levine (2003), for example, argue that common law is more flexible than civil law, and we focus on these two systems.

Anderlini et al.'s theory compares a flexible legal regime, where rules and penalties may be altered after innovation occurs, to a rigid legal system without any changes. A trade-off emerges between commitment and flexibility, and a time-inconsistency problem may arise. A flexible system may provide stronger incentives for innovation ex ante, but ex post lawmakers may choose policies that are less favourable for the innovator. For example, innovations that yield lower fuel consumption and $\mathrm{CO}_{2}$ emissions may spur lawmakers to change regulations or taxes ex post. This reduces the incentive to innovate. Anderlini et al. argue that rigid legal regimes reduce uncertainty regarding future legislation and encourage research and development (R and D) investment in early stage technologies. Comin and Hobijn (2009) argue that where legislative flexibility is high, new technology adoption is slower because oldtechnology firms may more easily lobby against new technologies. We note also that civil law has been shown to yield worse regulatory, judicial, financial, and economic outcomes, supporting the Legal Origins Theory by La Porta, Lopez-De-Silanes, and Shleifer (2008) (see also, e.g. Botero et al. 2004). This may lower the expected profitability of innovation in civil law countries. However, Fredriksson and Wollscheid (2015) report that civil law countries set stricter climate change regulation, which may increase the rate of clean technology innovation in those countries. In sum, the expected effect of legal system on clean technology innovation is ambiguous, and thus the relationship needs to be resolved empirically.

We use firm-level panel data on patenting of clean innovations (e.g. hybrid or electric) in the auto industry, and dynamic count data Poisson models. Our evidence suggests that the response to directed 
Table 1. Descriptive statistics.

\begin{tabular}{lrrrrrrr}
\hline & \multicolumn{3}{c}{ French civil law countries } & & \multicolumn{3}{c}{ Common law countries } \\
\cline { 2 - 3 } & Mean & Min & Max & & Mean & Min & \multicolumn{1}{c}{ Max } \\
\hline Fuel price USD & 0.822 & 0.349 & 1.720 & & 0.758 & 0.349 & 1.795 \\
R and D subsidies Mn USD & 1.290 & 0.020 & 6.252 & & 2.235 & 0.020 & 6.252 \\
Emission regulation & 1.945 & 0.263 & 20.707 & & 1.913 & 0.263 & 21.522 \\
Clean spillovers & 38.346 & 0.003 & 278.857 & & 65.641 & 0.012 & 559.290 \\
Dirty spillovers & 178.287 & 0.165 & 1371.485 & & 247.836 & 0.202 & 1370.158 \\
Own stock clean & 0.955 & 0.002 & 30.848 & & 0.990 & 0.002 & 48.360 \\
Own stock dirty & 0.829 & 0.001 & 46.816 & & 0.864 & 0.001 & 59.504 \\
Observations & & 9940 & & & 28,580 & \\
\hline
\end{tabular}

technical change is greater under rigid legal regimes, that is, in civil law countries.

\section{Empirical method}

To estimate the number of clean patents deposited by a firm, we adopt ADHMV's data and empirical specification:

$$
\begin{aligned}
P A T_{i t}= & \exp \left(\beta_{1} \ln F P_{i t-1}+\beta_{2} \ln S P I L L_{C, i t-1}\right. \\
& +\beta_{3} \ln S P I L L_{D, i t-1}+\beta_{4} \ln K_{C, i t-1} \\
& \left.+\beta_{5} \ln K_{D, i t-1}+\beta_{w} \ln w_{i t}+T_{t}\right) \eta_{i}+\mu_{i t},
\end{aligned}
$$

where $P A T_{i t}$ is the number of clean patents deposited by firm $i$ in year $t$, and $F P_{i t-1}$ is the tax inclusive fuel price faced by firm $i$ in year $t-1$. Since innovation is a pathdependent process, we include firms' stocks of clean and dirty patents ( $K_{C}$ and $K_{D}$, respectively). We control for the number of patents deposited by firms located in the same geographical area $\left(S P I L L_{C}\right.$ and $\left.S P I L L_{D}\right)$, recognizing that firms build on neighbours' knowledge. $w_{i t}$ represents additional control variables, $T_{t}$ year dummies, $\eta_{i}$ is firm conditional fixed effects, and $\mu_{i t}$ is the error term. We estimate Equation (1) for countries with rigid (civil law) and flexible (common law) legal systems, respectively.

To address endogeneity in dynamic firm-level fixedeffects Poisson models, Blundell, Griffith, and Van Reenen (1999), henceforth BGV, develop a controlfunction fixed-effect estimator. ${ }^{1}$ They condition on the pre-sample average of the dependent variable to proxy out the fixed effect. Our dataset may not possess the long pre-sample history of realizations of the dependent variable necessary to implement the BGV estimator; green patenting occurs mainly towards the end of the sample period. ADHMV propose using a control-function fixed-effects estimator (CFX) to deal with the fixed effect. They simultaneously estimate the main regression equation and a second equation allowing identification of the control-function from future data. We implement their novel technique but utilize the BVG estimator as a robustness check.

\section{Data}

With 1986-2005 firm-level data from ADHMV, we focus exclusively on 'triadic' clean patents (approve by the European, Japanese, and US patent offices) for firms headquartered in common law and French civil law countries, respectively. Using triadic patents eliminates patents of very low value.

To estimate the effect of directed technical change on clean innovation, we utilize the logarithm of fuel price data (average of diesel and gasoline prices) from 25 major countries compiled by ADHMV. The firm-specific fuel price index equals $\ln F P_{i t}=\sum w_{i c 0}^{F P} \ln F P_{c t}$, where $F P_{c t}$ is the tax-inclusive fuel price, and $w_{i c 0}^{F P}$ is the firm-specific weight based on the fraction of firm is patents (clean and dirty) granted in country $c$ during 1965-1985. According to this specification, firms secure patents where they expect future sales. Using weights based on the patent portfolio of each firm averaged over the 1965-1985 (pre-sample) period ensures that the weights are weakly exogenous, as patent location could be influenced by shocks to innovation.

We divide the sample based on whether firms are headquartered in French civil law (497 firms) or common law (1429 firms) countries (La Porta, Lopez-DeSilanes, and Shleifer 2008). ${ }^{2}$ We focus on these two legal systems because they present the sharpest contrast in terms of jurisprudence and flexibility (see Beck,

\footnotetext{
${ }^{1}$ The firm's own stock of patents is included among the regressors.

${ }^{2}$ Common law countries included: Bermuda, Hong Kong, Belize, Dominica, Thailand, Singapore, South Africa, Israel, UK, Australia, India, USA, Ireland, Sri Lanka, Cayman Islands, New Zealand, Barbados. French civil law countries included: Peru, Netherlands, Turkey, Italy, Belgium, France, Indonesia, Brazil, Luxembourg, Russia, Netherlands Antilles, Greece, Venezuela, Argentina, Mauritius, Malta, Spain.
} 
Demirgüç-Kunt, and Levine 2003). During the time period studied, clean technology was relatively new and firms faced uncertainty regarding the location of future sales, so 'home bias' should make local legal institutions particularly important. We therefore take the view that only one legal system matters for each firm's $\mathrm{R}$ and $\mathrm{D}$ decision. ${ }^{3}$

We control for patent stock, calculated using the perpetual inventory method (Peri 2005): $K_{z, i t}=$ $P A T_{z, i t}+(1-\delta) K_{z, i t-1}$, where $z \in\{$ Dirty, Clean $\}$, and $\delta=0.20$, following the literature. We control for firm-specific spillover pools of knowledge, calculated for firm $i$ as $S P I L L_{z, i t}=\sum_{c} \omega_{i c 0}^{S} S P I L L_{z, c t}$, where $\omega_{i 0}^{S}$ is the share of all firm $i$ s inventors in country $c$ during years 1965-1985, and SPILL $L_{z, c t}=\sum_{j \neq i} \omega_{j c 0}^{S} K_{z, j t}$ is the spillover pool in country $c$ at time $t$, that is, it is the sum of all other firms' patent stocks weighted by the number of inventors those firms have in that country. ${ }^{4}$ See Table 1 for descriptive statistics.

\section{Empirical results}

Table 2 reports estimations of Equation (1). Panel A reports estimations using the flow of clean patents in firms headquartered in French civil law countries only. Panel B shows the corresponding estimations but using common law country data only. Models (1)-(3) and (5)-(7) show CFX estimator results; Models (4) and (8) report BGV estimator results. Models (2)-(3) and (6)-(7) include a measure of public $\mathrm{R}$ and $\mathrm{D}$ subsidy expenditures on energy efficiency in transportation (Mn USD 2010 prices; IEA 2015). Models (3) and (7) add a measure of automobile tailpipe emission regulations (Dechezleprêtre, Neumayer, and Perkins 2015). Regarding the R and $\mathrm{D}$ subsidy expenditures measure, the inventor's country of residence is used, similarly as for the knowledge spillover variables. The measure of emission regulation is built using the same weights as the fuel price variable. These two controls are important as they are alternative ways (other than fuel taxes) for governments to direct technical change.

Comparing patenting by firms headquartered in civil law versus common law countries, we find that while the coefficient on the fuel price is positive and significant in both groups of countries (disregarding Model (1), where Fuel Price is insignificant), it is substantially larger in civil law countries. Models (3) and (7), for example, indicate that the fuel price elasticity is 2.321 in civil

Table 2. Directed technical change and legal heritage.

\begin{tabular}{|c|c|c|c|c|c|c|c|c|}
\hline \multirow[b]{3}{*}{ Estimator } & \multicolumn{4}{|c|}{$\begin{array}{c}\text { Panel A } \\
\text { Civil law countries }\end{array}$} & \multicolumn{4}{|c|}{$\begin{array}{c}\text { Panel B } \\
\text { Common law countries }\end{array}$} \\
\hline & (1) & (2) & (3) & (4) & (5) & (6) & (7) & (8) \\
\hline & CFX & CFX & CFX & BGV & CFX & CFX & CFX & BGV \\
\hline Fuel price & $\begin{array}{c}1.812 \\
(1.487)\end{array}$ & $\begin{array}{l}2.346^{*} \\
(1.315)\end{array}$ & $\begin{array}{r}2.321^{*} \\
(1.305)\end{array}$ & $\begin{array}{l}1.559^{* *} \\
(0.655)\end{array}$ & $\begin{array}{l}1.106^{* *} \\
(0.504)\end{array}$ & $\begin{array}{l}1.214^{* *} \\
(0.522)\end{array}$ & $\begin{array}{l}1.195^{* *} \\
(0.524)\end{array}$ & $\begin{array}{l}1.067^{* * *} \\
(0.384)\end{array}$ \\
\hline$R$ and $D$ subsidies & & $\begin{array}{c}-0.065 \\
(0.127)\end{array}$ & $\begin{array}{l}-0.110 \\
(0.140)\end{array}$ & & & $\begin{array}{l}0.017 \\
(0.096)\end{array}$ & $\begin{array}{l}0.020 \\
(0.095)\end{array}$ & \\
\hline Emission regulation & & & $\begin{array}{c}-0.475 \\
(0.298)\end{array}$ & & & & $\begin{array}{c}0.031 \\
(0.434)\end{array}$ & \\
\hline Clean spillovers & $\begin{array}{l}0.587^{* * *} \\
(0.193)\end{array}$ & $\begin{array}{l}0.596^{* * *} \\
(0.227)\end{array}$ & $\begin{array}{l}0.715^{* * *} \\
(0.219)\end{array}$ & $\begin{array}{l}0.589^{* *} \\
(0.233)\end{array}$ & $\begin{array}{l}-0.167 \\
(0.145)\end{array}$ & $\begin{array}{c}-0.174 \\
(0.174)\end{array}$ & $\begin{array}{c}-0.174 \\
(0.170)\end{array}$ & $\begin{array}{l}0.324^{* *} \\
(0.163)\end{array}$ \\
\hline Dirty spillovers & $\begin{array}{l}-0.420^{* * *} \\
(0.157)\end{array}$ & $\begin{array}{l}-0.438^{* * *} \\
(0.159)\end{array}$ & $\begin{array}{l}-0.489^{* * *} \\
(0.157)\end{array}$ & $\begin{array}{l}-0.447^{* *} \\
(0.197)\end{array}$ & $\begin{array}{l}0.307^{* *} \\
(0.151)\end{array}$ & $\begin{array}{l}0.305^{* *} \\
(0.142)\end{array}$ & $\begin{array}{l}0.302^{* *} \\
(0.141)\end{array}$ & $\begin{array}{c}-0.210 \\
(0.136)\end{array}$ \\
\hline Own stock clean & $\begin{array}{l}0.422^{* * *} \\
(0.072)\end{array}$ & $\begin{array}{l}0.440^{* * *} \\
(0.105)\end{array}$ & $\begin{array}{l}0.429^{* * *} \\
(0.100)\end{array}$ & $\begin{array}{l}0.800^{* * *} \\
(0.075)\end{array}$ & $\begin{array}{l}0.541^{* * *} \\
(0.056)\end{array}$ & $\begin{array}{l}0.583^{* * *} \\
(0.059)\end{array}$ & $\begin{array}{l}0.583^{* * *} \\
(0.059)\end{array}$ & $\begin{array}{l}0.967^{* * *} \\
(0.054)\end{array}$ \\
\hline Own stock dirty & $\begin{array}{l}0.374^{* * *} \\
(0.048)\end{array}$ & $\begin{array}{l}0.350^{* * *} \\
(0.053)\end{array}$ & $\begin{array}{l}0.380^{* * *} \\
(0.052)\end{array}$ & $\begin{array}{l}0.266^{* * *} \\
(0.065)\end{array}$ & $\begin{array}{l}0.281^{* * *} \\
(0.038)\end{array}$ & $\begin{array}{l}0.297^{* * *} \\
(0.040)\end{array}$ & $\begin{array}{l}0.297^{* * *} \\
(0.040)\end{array}$ & $\begin{array}{l}0.138^{* *} \\
(0.068)\end{array}$ \\
\hline Observations & 9940 & 9940 & 9940 & 9940 & 28580 & 28580 & 28580 & 28580 \\
\hline Firms & 497 & 497 & 497 & 497 & 1429 & 1429 & 1429 & 1429 \\
\hline
\end{tabular}

Dependent variable is clean patent flow. Standard errors in parenthesis are clustered at the firm level. ${ }^{* * *} p<0.01 ;{ }^{* *} p<0.05 ;{ }^{*} p<0.10$.

\footnotetext{
${ }^{3}$ Another option involves assigning a percentage of expected sales in common and French civil law countries, as with fuel prices. However, this option is unfeasible due to data and parameter interpretation problems. Fuel price data lack satisfactory availability outside the 25 countries used by ADHMV in the fuel price construction. Furthermore, interpreting interacted variable coefficients with the ADHMV estimator is clearly beyond the scope of this article.

${ }^{4}$ See Appendix C, ADHMV, for a complete description of the variables' construction.
} 
law countries while it is 1.195 in common law countries. The Welch $t$-statistic (a generalization of the student $t$-test used to compare regression coefficients fitted to independent datasets (Welch 1947)) rejects the null hypothesis of no statistical difference between Fuel price coefficients: Model 2 vs. 6 (Welch $t$-statistic 83.6); Model 3 vs. 7 (83.7); Model 4 vs. 8 (49.6). Using the insignificant Fuel price coefficient in Model (1) for comparisons is not meaningful. The results do reveal the importance of controlling for $\mathrm{R}$ and $\mathrm{D}$ subsidies, which are aimed at influencing innovation incentives. ${ }^{5}$ Rigid law with lower uncertainty regarding future legislation appears to encourage clean technology innovation.

Firms' own stocks of clean and dirty patents, as well as other local inventors' such stocks, tend to affect patenting. This is consistent with innovation being a path dependent process and that innovators build on the existing own and local colleagues' stocks of knowledge.

\section{Conclusion}

Consistent with recent theoretical work, our evidence suggests that the rigidity of legal systems affects the innovation response to directed technical change. Clean technology patenting is more responsive to changes in tax-inclusive fuel price changes in civil law countries (more rigid legal systems) compared to common law countries (relatively flexible legal systems). Legal regimes thus have implications for the feasibility of addressing climate change through inducing technological innovation through market-oriented policies.

\section{Acknowledgements}

We thank Antoine Dechezleprêtre and John Van Reenen for kindly sharing data, and the helpful referee for useful comments. Fredriksson gratefully acknowledges financial support from the College of Business, University of Louisville. The usual disclaimers apply.

\section{Disclosure statement}

No potential conflict of interest was reported by the authors.

\section{Funding}

This work was supported by the College of Business, University of Louisville.

\section{References}

Acemoglu, D., P. Aghion, L. Bursztyn, and D. Hemous. 2012. "The Environment and Directed Technical Change." American Economic Review 102 (1): 131-166. doi:10.1257/aer.102.1.131.

Aghion, P., A. Dechezleprêtre, D. Hémous, R. Martin, and J. Van Reenen. 2016. "Carbon Taxes, Path Dependency and Directed Technical Change: Evidence from the Auto Industry.” Journal of Political Economy 124 (1): 1-51. doi:10.1086/684581.

Anderlini, L., L. Felli, G. Immordino, and A. Riboni. 2013. "Legal Institutions, Innovation, and Growth." International Economic Review 54 (3): 937-956. doi:10.1111/iere.2013.54.issue-3.

Beck, T., A. Demirgüç-Kunt, and R. Levine. 2003. "Law and Finance: Why Does Legal Origin Matter?" Journal of Comparative Economics 31: 653-675. doi:10.1016/j. jce.2003.08.001.

Blundell, R., R. Griffith, and J. Van Reenen. 1999. "Market Share, Market Value and Innovation in a Panel of British Manufacturing Firms.” Review of Economic Studies 66 (3): 529-554. doi:10.1111/roes.1999.66.issue-3.

Botero, J. C., S. Djankov, R. L. Porta, F. Lopez-de-Silanes, and A. Shleifer. 2004. "The Regulation of Labor." The Quarterly Journal of Economics 119: 1339-1382. doi:10.1162/0033553042476215.

Comin, D., and B. Hobijn. 2009. "Lobbies and Technology Diffusion." The Review of Economics and Statistics 91 (2): 229-244. doi:10.1162/rest.91.2.229.

Dechezleprêtre, A., E. Neumayer, and R. Perkins. 2015. "Environmental Regulation and the Cross-Border Diffusion of New Technology: Evidence from Automobile Patents." Research Policy 44 (1): 244-257. doi:10.1016/j.respol.2014.07.017.

Fredriksson, P. G., and J. R. Wollscheid. 2015. "Legal Origins and Climate Change Policies in Former Colonies." Environmental and Resource Economics 62: 309-327. doi:10.1007/s10640-015-9957-2.

IEA. 2015. "IEA Energy Technology Research and Development database." data.iea.org.

La Porta, R., F. Lopez-De-Silanes, and A. Shleifer. 2008. "The Economic Consequences of Legal Origins." Journal of Economic Literature 46 (2): 285-332. doi:10.1257/jel.46.2.285.

Peri, G. 2005. "Determinants of Knowledge Flows and Their Effect on Innovation." Review of Economics and Statistics 87 (2): 308-322. doi:10.1162/0034653053970258.

Welch, B. L. 1947. "The Generalization of 'Student's' Problem When Several Different Population Variances are Involved." Biometrika 34: 28-35.

\footnotetext{
${ }^{5}$ See also ADHMV.
} 